\title{
List Księdza Jana i jego średniowieczne przekazy rękopiśmienne w zbiorach polskich
}

a sprawą powieści sławnego włoskiego mediewisty i pisarza Umberto Eco ${ }^{1}$ spopularyzowany został znów dawno już zapomniany List Księdza Jana² - zadziwiający tekst o jeszcze bardziej zadziwiającej historii; jeden z tych paradoksalnych przypadków w dziejach, kiedy krótkie, apokryficzne pismo, przekazujące całkowicie fikcyjne treści, uzyskało rozgłos i znaczenie polityczne zupelnie nieproporcjonalne do swej wartości poznawczej, zawartości merytorycznej i faktycznego celu. Geneza tego „listu”, która stała się osnowa powieści Eco, umyka historykom; jesteśmy zdani całkowicie na domysły. Jednak fascynująca historia rozwoju legendy Księdza Jana, jej odgałęzień i oddziaływania na kolejne pokolenia, jest znacznie lepiej uchwytna i zaprząta umysły badaczy od wielu dziesięcioleci, należąc do klasycznych przykładów, na podstawie których omawiane są mechanizmy funkcjonowania umysłowości średniowiecznej.

Postać Księdza Jana po raz pierwszy spotykamy w źródłach w 1145 r., gdy opowiedział o niej Ottonowi z Fryzyngi, niemieckiemu encyklopedyście i kronikarzowi, a zarazem wujowi cesarza Fryderyka I Barbarossy, biskup Hugon z Dżabali (starożytne Byblos), jednej z diecezji w niedawno ustanowionym łacińskim Wschodzie 3 . Według biskupa Hugona, kilka lat wcześniej bracia Samiardi, władcy Persów i Medów, zostali zaatakowani i pokonani przez niejakiego Jana, króla i kapłana w jednej osobie, przywódcę chrześcijańskiego, aczkolwiek nestoriańskiego, państwa znajdującego się na najdalszym wschodzie. Ksiądz Jan miał zdobyć Ekbatanę, stolicę wspomnianych braci, po czym w trzydniowej morderczej bitwie zdruzgotać połączone siły Persów, Medów i Asyryjczyków. Następnie postanowil udać się na pomoc Jerozolimie, ale na przeszkodzie stanęły mu potężne wody rzeki Tygrys, przez które, mimo kilkuletnich starań, nie zdołał przeprawić swoich wojsk; przerwał więc wyprawę i powrócil do domu. W dalszej części relacji Otton z Fryzyngi wyjaśnił motywy działania Księdza Jana - władca ów wywodził się od biblijnych Trzech Króli i dlatego pragnął pokłonić się Chrystusowi u jego kołyski, w Jerozolimie ${ }^{4}$. 
Tyle Otton z Fryzyngi; jak się to wszystko jednak ma do historii? Faktycznie Ksiądz Jan nigdy nie istniał. Niemniej biskup Hugon to postać ponad wszelką wątpliwość historyczna, a dzieło Ottona z Fryzyngi cieszy się wśród nowożytnych historyków wysoka oceną jako wiarygodne, krytyczne i pelne interesujących informacji. Tak więc do spotkania w Viterbo na pewno doszlo, a relacji biskupa Hugona nie sposób zbyć jako opartej na łatwowierności. I rzeczywiście są w niej ziarna prawdy. Opisana trzydniowa bitwa jest zgodnie identyfikowana z pogromem wojsk seldżuckich sultana Sandżara z rąk Mongołów, z plemienia Kara Kitaj, pod wodzą gurchana Jelü Taszy. Batalia miała miejsce we wrześniu 1141 r. w stepie na Równinie Katwańskiej na wschód od Samarkandy. W jej wyniku ugruntowane zostało państwo kara-kitajskie, w którym faktycznie ważną rolę odgrywali chrześcijanie wyznania nestorianskiego, chociaż gurchan, mimo sympatyzowania z chrześcijanami (jego syn i następca mial na imię Eliasz), sam wiary tej nie przyjął nigdy ${ }^{5}$. Wieści o środkowoazjatyckim państwie kara-kitajskim zapewne dały asumpt do wyklucia się legendy na temat państwa Księdza Jana. Miano pokonanych Samiardi z Listu, odnoszone do dwóch lub więcej braci, to zapewne przekształcona forma imienia Sandżar. Nie jest to zaskakujące, praktyką bowiem władców seldżuckich w owych czasach było opieranie się na więzach rodzinnych w organizowaniu administracji swego rozległego imperium. Dalsza czẹść Listu jest już głównie fikcją, aczkolwiek zbierającą różnorodne ziarna faktyczne w jedną całość.

Historycy różnie interpretują relację Hugona. Steven Runciman traktuje ją jako bajkę ku pokrzepieniu serc ${ }^{6}$. Ch.F. Beckingham argumentuje jednak, że imię Księdza Jana było już znane w Europie wcześniej i że intencje biskupa Hugona były wprost przeciwne, starał się przekonać najbardziej wpływowe osoby na Zachodzie (papieża - rozmowa ma miejsce w Viterbo, cesarza - Otto z Fryzyngi należy do najbliższego otoczenia Fryderyka Barbarossy), iż na pomoc ze wschodu nie ma co liczyć, gdyż Jan po kilkuletnich próżnych wysilkach celem sforsowania Tygrysu zrezygnował i się wycofał. A dlaczego Hugon mialby to robić? Gdyż wiadomości o chrześcijańskim państwie na wschodzie, a także kontakty z nim istniały już wcześniej.

Już od VI w. krążyły w Europie informacje o istnieniu wyznawców Chrystusa w Indiach - legendy o grobie św. Tomasza tamże i skupionych wokół niego wiernych. W 1122 r. miał odwiedzić papieża Kaliksta II arcybiskup Indii. Wiadomość tę poświadcza anonimowy traktat De adventu patriarchae Indorum ad Urbem sub Calixto papa secundo, charakteryzujący się dosyć daleko posuniętą dowolnością w traktowaniu materiału faktograficznego, oraz całkiem wiarygodny list opata Odona z Rheims ${ }^{7}$. Szkopuł tkwi w tym, jak należy rozumieć w obydwu przekazach termin Indie. Średniowieczna wiedza geograficzna rozróżniała bowiem „trzy Indie”, określając je różnymi przymiotnikami (Prima, Maior, Superior; Secunda, 
Minor, Inferior; oraz Tertia, Ultima), z których pierwsze dwa określenia odnosiły się do różnie rozumianych części Indii azjatyckich, trzecie zaś do leżącej w Afryce Etiopii. W przypadku wizyty patriarchy „indyjskiego” w 1122 r. owo ostatnie rozumienie zdaje się mieć najwięcej zwolenników.

Kolejne wydarzenie w dziejach rozwoju legendy o orientalnym władcy chrześcijańskim to list papieża Aleksandra III, adresowany karissimo in Christo filio Iohanni, illustri et magnifico Indorum regi, wystawiony w Wenecji 27 września $1177 \mathrm{r}^{8}$ Można by to uznać za terminus post quem non, gdyby nie wątpliwości, czy list Aleksandra III był rzeczywiście odpowiedzią na List Księdza Jana. Z samego pisma papieskiego bynajmniej to nie wynika. Co więcej, wspomniane jest tam, że wiadomości na temat króla Jana dostarczyła papieżowi konkretna osoba, jego dworzanin i medyk, mistrz Filip. Ton listu pozwala również wnosić, że jego adresat to też konkretna osoba: znowu cesarz Etiopii ${ }^{9}$. Dalsze losy tego listu nie są nam znane.

W tej sytuacji postawione zostało pytanie, czy List Księdza Jana w ogóle zaistniał w życiu publicznym w XII w. i czy zasadnie powszechnie nazywa się go falsyfikatem? Posługiwanie się terminem falsyfikat implikuje akcję lub próbę akcji dyplomatycznej, podczas gdy źródła nie dają dostatecznych podstaw ku takiemu mniemaniu. Co więcej, „list” ów nawet nie stara się przypominać dokumentu o charakterze oficjalnym; ignoruje wszelkie konwencje dyplomacji, z miejscem i czasem wystawienia na czele! W tej sytuacji Ch.F. Beckingham zasadnie uznał intencje autora lub autorów omawianego tekstu za wylącznie literackie ${ }^{10}$.

U podstaw zrodzenia się i rozwoju mitu o Księdzu Janie leżą niepowodzenia i rozczarowania związane z walkami o Ziemię Świętą w XII w. Kiedy więc dotarly na Zachód wieści o klęskach militarnych wyznawców islamu w zmaganiach $\mathrm{z}$ Mongolami, zmieszały się one $\mathrm{z}$ wcześniej już funkcjonującymi informacjami o chrześcijańskim państwie gdzieś w Indiach (czyli Etiopii), by wytworzyć legendę o potężnym władcy chrześcijańskim na wschodzie. Tymczasem w XIII w. Mongołowie stali się rzeczywistością, i to straszliwa, w samej Europie. Europejczycy podróżujący w tych czasach na wschód - Pian de Carpine (1246), Wilhelm Ruysbroek (1253-1255), Marco Polo (1254?-1324) i Odoryk z Pordenone (1286-1331) - mieli nadzieję odnaleźć legendarnego władcę. Negatywny wynik ich poszukiwań, a przede wszystkim odbyta w początkach XIV w. podróż Jordanusa de Sévéraca do Indii, rozwiały nadzieje na odnalezienie Księdza Jana (lub jego syna Dawida) na Dalekim Wschodzie. W XIV, a przede wszystkim XV w. poszukiwania kierowały się na południe, do Afryki, i zostały uwieńczone sukcesem. W wyniku nawiązanych kontaktów, na początku XV w. w Europie pojawiają się posłowie etiopscy. Bawia w Wenecji (1402), Bolonii (1408) i na dworze Alfonsa V aragońskiego (1427). W 1439 r. papież Eugeniusz IV wysyła list do cesarza Etiopii - Księdza Jana. Etiopczycy uczestniczą także w 1441 r. w soborze w Fer- 
rarze - Florencji, poświęconym zjednoczeniu kościołów. Przez następne lata poszukiwaniem drogi morskiej do Indii-Etiopii wokół Afryki energicznie zajmują się Portugalczycy, co stanowi odrębny rozdział historii odkryć geograficznych. Tak więc ostatecznie chrześcijańskie państwo ukryte za krajami muzułmańskimi zostało znalezione - Ksiądz Jan się ziścił! - aczkolwiek rzeczywistość okazała się dalece uboższa niż legenda.

Kiedy jednak faktycznie powstal List Księdza Jana? Pismo adresowane jest do cesarza bizantyjskiego Manuela Komnena, który panował w latach 1143-1180. Daty te należy uznać za najszersze granice chronologiczne zaistnienia listu. Kronikarz francuski Alberyk z Trois Fointaines stwierdza w swojej kronice, że pismo to pojawiło się na Zachodzie około $1165 \mathrm{r} .{ }^{11}$ Datacja ta jest podważana w literaturze, ze względu na oddalenie w czasie powstania kroniki Alberyka (1232-1252) od opisywanych wydarzeń oraz na brak odniesien do tego listu ze strony Ottona z Fryzyngi ${ }^{12}$.

Treść Listu przesycona jest zaledwie pozornie maskowaną niechęcią do Bizancjum i Bizantyjczyków. List zaczyna się od formuly intytulacyjnej: Ksiądz (presbiter) Jan, z Bożej Łaski pan panów, pozdrawia Manuela. Zaraz potem natrafiamy na pierwszy afront - basileus nazwany jest Romeon gubernator, co najbliżej oddaje zarzadzajacy Rzymianami lub namiestnik Rzymian, w każdym razie nie cesarz. Z następnych zdań wynika, że nie jest to pierwszy kontakt nadawcy i odbiorcy listu i że Jan chciałby zadać niewinne pytanie: Czy Manuel jest wyznawca właściwej wiary?, tak jakby tego rodzaju pytania należały do normy protokołu dyplomatycznego. Doniesiono mu bowiem, i tu następuje kolejna uszczypliwość, że Greczynkowie (w oryginale Graeculi) uznają swego władcę za Boga. Jan natomiast otwarcie wyznaje, że on sam jest człowiekiem i wie, że Manuel jest człowiekiem również, i zaprasza go, by zamieszkał w jego kraju, a on godziwie go tam uposaży. W nawiązaniu do czego roztacza przed Manuelem opis potęgi i bogactwa swego królestwa - trzech Indii.

W tym miejscu rozpoczyna się druga część listu, w której Bizancjum i Bizantyjczycy nie występują już jako przedmiot narracji; część druga zawiera wykład tego, jak powinno wyglądać państwo najpotężniejszego władcy chrześcijańskiego, w domyśle: w przeciwieństwie do cesarstwa bizantyjskiego.

Pierwszym elementem opisu jest wykonywanie władzy. Ksiądz Jan jest faktycznym zwierzchnikiem siedemdziesięciu dwóch królów, którzy płacą mu trybut. Jako władca chrześcijański wspomaga i broni ubogich, ślubował też odwiedzić wraz ze swym wojskiem Grób Pański w Ziemi Świętej. W następnej kolejności opisane sa ziemie, którymi włada - siedemdziesiąt dwie prowincje, gdzie znaleźć można tylko to, co dobre, piękne, drogocenne i potężne. Wymieniony jest caly szereg zwierząt egzotycznych i legendarnych: słonie, dromadery, wielbłądy, hipopotamy, kro- 
kodyle, pantery, dzikie osły, lwy białe i czerwone, a także trudne do zidentyfikowania bestie legendarne, takie jak methagallinaria, cametheternis, thinsirete ${ }^{13} \mathrm{i}$ wiele innych. Kraj oplywa w miód i mleko, a wszelakie bestie jadowite, jak np. węże, są nieobecne. W tym ostatnim względzie nieco później dochodzi do sprzeczności, gdy wspomniane sa jadowite węże w lasach pieprzowych. Ziemia rodzi cudowne zioła zwane assidios, które dają moc wywoływania mocy nieczystych, na drzewach rośnie pieprz. Bije magiczne źródło, którego woda sprawia, że człowiek, który się z niego napije, do końca życia jest uodporniony na choroby, a wygląda zawsze jakby miał trzydzieści dwa lata. Znajduje się tam morze piaskowe, które bezustannie się porusza i którego w żaden sposób przebyć się nie da. Do morza tego wpada rzeka kamieni, po drugiej stronie której mieszka dziesięć zaginionych plemion izraelskich, również poddanych Janowi. Jest także rzeka podziemna, jej koryto pełne jest kamieni szlachetnych. Tylko koni, rzecz ciekawa, jest mało, a te, które można tam spotkać, sa mizerne.

Trzecia część opisu Indii traktuje o wojskowości i symbolice wladzy. Gdy Jan wybiera się na wyprawę wojenną, wojsko jego dzieli się na trzynaście hufców liczących po dziesięć tysięcy konnicy i sto tysięcy piechoty każdy. Przed każdym hufcem niesiony jest drogocenny krzyż, pełniący rolę chorągwi, za wojskiem zaś podążają ogromne tabory. W czasie pokoju oznaką wladzy Jana jest prosty krzyż drewniany, na pamiątkę Męki Pańskiej, złote naczynie wypełnione ziemią, mające za zadanie przypominać władcy, że z prochu powstal i w proch się obróci, oraz srebrne naczynie pełne złota, ku podkreśleniu jego panowania doczesnego.

Część czwarta zajmuje się moralnością społeczeństwa Trzech Indii. Poddani Jana nie kłamią, nie cudzołożą i miłują się nawzajem; nie ma wśród nich zła, władca zaś co rok nawiedza wraz ze swym wojskiem relikwie świętego Daniela. Kolejna część opisuje cuda dworu Janowego. Przy opisie wspaniałości pałacu znów napotykamy niekonsekwencje. W kraju, gdzie zło się nikogo nie ima, bramy pałacu są specjalnie zabezpieczone na wypadek, gdyby ktoś chciał się wkraść z trucizną, przed budowlą zaś jest plac pojedynkowy oraz stoi wymyślna konstrukcja, na której szczycie spoczywa specjalne lustro, mające tę właściwość, że natychmiast pokazuje władcy knowania jego wrogów.

Ksiądz Jan ma wiele nałożnic, jednak cieleśnie obcuje $\mathrm{z}$ każdą z nich tylko cztery razy do roku, i to wyłącznie w celu prokreacji. Przy stole zasiadają z nim, według specjalnej kolejności, prałaci jego królestwa. Posługę religijną w kaplicy pałacowej sprawują opaci. Na zakonczenie Jan wyjaśnia, dlaczego kontentuje się podrzędnym tytułem prezbitera. Tłumaczy adresatowi, że kiedy urzędy na jego dworze obsadzone są przez królów, prałatów i książąt, nie godzi się mu przybierać tytułu $\mathrm{z}$ tego grona; co więcej, pragnie w ten sposób podkreślić swą pokorę. 
Na koniec przestrzega Manuela przed swoją potęga następującymi słowy: Si potes dinumerare stellas caeli et arenam maris, dinumera etiam dominium nostrum et potestatem nostram.

List Księdza Jana, jak wykazali kolejni badacze, jest zlepkiem wiadomości zaczerpniętych $\mathrm{z}$ różnorodnych tekstów i tradycji średniowiecznych ${ }^{14}$. Odnaleźć w nim można echa i cytaty z popularnej literatury o Aleksandrze Wielkim (zwłaszcza Historia de proeliis), dzieł encyklopedycznych (Izydor z Sewilli, Ekkehard z Aura), a nawet literatury żydowskiej (Eldad-had-Dani). Leonard Olschki zainicjował interpretowanie Listu Księdza Jana jako średniowiecznej literatury utopijnej ${ }^{15}$. Dyskutowany jest także język, w którym powstał List, a więc kwestia autorstwa. Większość historyków zajmujących się tym pismem wypowiedziała się za lacina, aczkolwiek nie brakło głosów optujących za językiem greckim. Wszelką argumentację w tej kwestii osłabia jednak wymowa faktu, że jak dotąd nie odkryto żadnej kopii greckiej, a przekłady serbski i ruski dokonane zostały z laciny. Pozostaje nierozstrzygnięta także ostatecznie kwestia, gdzie powstał List Księdza Jana. W tej materii ścierają się dwa przeciwstawne poglądy. Według zwolenników pierwszego, został on napisany w Europie Zachodniej na podstawie tekstów dostępnych na miejscu. Więcej zwolenników ma jednak teza, że napisano go na łacińskim Wschodzie, a jego autor pozostawał także w orbicie tradycji arabskich i żydowskich, których ślady dają się uchwycić w tekście.

Łacina była najprawdopodobniej językiem oryginału Listu Księdza Jana. Od samego początku był on jednak traktowany z wielką swobodą - dowodem na to sa interpolacje dolączone do tekstu pierwotnego już w pierwszych latach funkcjonowania. List ten był również bardzo rozpowszechniony w przekładach na języki narodowe: angielski, francuski, irlandzki, langwedocki, niemiecki oraz włoski ${ }^{16}$. Teksty w językach narodowych żyły życiem własnym jako literatura popularna, a adresatem bywał w nich już nie tylko cesarz bizantyjski, lecz także cesarz rzymski lub król francuski. List wcześnie trafił też pod prasy drukarskie ${ }^{17}$.

List Księdza Jana był wielokrotnie analizowany i drukowany. Jednak najwięcej uwagi poświęcil mu dziewiętnastowieczny niemiecki uczony Friedrich Zarncke, który odnalazł blisko sto rękopisów, dokonał ich klasyfikacji i oglosił w swej monografii gruntowną edycję krytyczną ${ }^{18}$. Zarncke zrekonstruował tekst pierwotny i wyróżnił pięć późniejszych interpolacji, które datował na lata od 1150-1160 do 1300. Owe oswobodzenie tekstu pierwotnego od naleciałości późniejszych jest najprawdopodobniej najtrwalszym osiagnięciem jego pracy. Samo wydanie, z perspektywy przeszło stu lat, ma liczne słabe strony: Zarncke nie dotarł osobiście do wszystkich znanych mu przekazów, a informacje, które otrzymywał z drugiej ręki, nie zawsze były ścisłe. Ponadto od ukazania się tej edycji odkryto dalsze sześćdziesiąt rękopisów, których włączenie do analizy może częściowo zmodyfikować ustalenia 
Zarnckego. Mimo to badacze wskazujący na konieczność reedycji nie spodziewają się przewrotu $w$ dotychczasowych ustaleniach; ponowne przeanalizowanie tradycji tekstowej jest potrzebne przede wszystkim ze względu na nadzieje uchwycenia nowych związków z przekładami na języki narodowe.

W zbiorach polskich także zachowały się odpisy Listu Księdza Jana. Zarncke wiedział o przekazie zawartym w przechowywanym obecnie w Bibliotece Narodowej kodeksie wilanowskim ${ }^{19}$. Wiadomość o nim otrzymal od Wladysława Wisłockiego. Nie zapoznał się jednak ze wspomnianym rękopisem osobiście, lecz zawierzył edycji Hipolita Kownackiego ${ }^{20}$. Ewidentnie jednak zawiodla go znajomość języka polskiego lub otrzymane tłumaczenie. $Z$ wywodów Kownackiego zrozumiał, że manuskrypt ów pochodzi z XII stulecia, w co nie był skłonny wierzyć i skorygował to na wiek XIII ${ }^{21}$. Sam przekaz uznał za pełen błędów (choć dopuszczal nieścisłe odczyty Kownackiego) i dostrzegał w nim odległe podobieństwa do rękopisu Reg. lat. 657, przechowywanego w Bibliotece Watykańskiej, datowanego na przetom XII i XIII w. ${ }^{22}$

Konfrontacja zawartości rękopisu wilanowskiego z edycją Zarnckego wykazuje, że mamy do czynienia $\mathrm{z}$ tekstem oryginalnym, bez interpolacji, upstrzonym jedynie błędami pisarskimi. Omawiany przekaz nie pomija żadnego większego elementu tekstu. Wyróżnia go jedynie pominięcie fragmentu zawierającego opis piętrowej konstrukcji, na której spoczywa cudowne lustro Księdza Jana, i dodane zakończenie: Tu autem domine nostri miserere. Deo gratias. Alleluya! W świetle ewidentnego nieporozumienia co do datacji rękopisu wilanowskiego przez Zarnckego, na bliższe wnioski dotyczące miejsca tego przekazu w stemma codicum należy zaczekać do nowej edycji krytycznej.

Zarncke znał także za pośrednictwem Wisłockiego dwie inne kopie Listu Księdza Jana ze zbiorów Biblioteki Jagiellońskiej, zawarte w rękopisach 431 (k. 116r119 r) ${ }^{23}$ i 1607 (s. 739-752) ${ }^{24}$. Analiza ich treści wykazała jednak, że pierwszy $\mathrm{z}$ nich należy do grupy zawierającej interpolację $\mathrm{B}^{25}$, drugi zaś interpolację $\mathrm{D}^{26}$, tak więc żaden $\mathrm{z}$ zachowanych przekazów, zarówno krakowski jak i pochodzący z Biblioteki Wilanowskiej, nie mógł być odpisem sporządzonym na podstawie któregokolwiek z pozostałych.

Do 1944 r. istniał także jeszcze jeden odpis, który być może wykazywał dalej idące podobienstwa do przekazu z rękopisu wilanowskiego. Znajdował się w XVI-wiecznym kodeksie tzw. Świdzińskiego, zwanym także kodeksem „Rocznika Krasińskich”. Kownacki wykorzystał go wprawdzie w swojej książce, ale jego wydanie jest tak bałamutne, a informacje zamieszczone w przedwojennych opisach są tak lakoniczne, że wszelkie wnioskowanie na tych podstawach jest niemożliwe ${ }^{27}$. 


\section{Przypisy}

${ }^{1}$ Umberto Eco, Baudolino, przełożył Adam Szymanowski, Warszawa 2001.

${ }^{2} \mathrm{~W}$ thumaczeniu Adama Szymanowskiego tytuł omawianego listu brzmi: List Presbitera Johamesa. Jest to wierny przekład brzmienia łacinskiego. W polskiej historiografii, zwłaszcza nowszej. używa się najczęściej tytulu List Księdza Jana, aczkolwiek tradycyjna, staropolska wersja mówila o Popie Janie.

${ }^{3}$ Poniższy zarys opiera się na następujących pracach: F. Zarncke, Der Priester Johannes, „Abhandlungen der philologisch-historischen Classe der Königl. Sächsischen Gesellschaft der Wissenschaften", Erste Abhandlung: Bd. VII, No. VIII, Leipzig 1879, Zweite Abhandlung: Bd. VIII, No. I, Leipzig 1876 [reprint: Hildesheim - New York 1980]; M. G o sm a n, La lettre du Prêtre Jean. Les versions en ancien français en ancien occitan. Textes et commentaires, Groningen 1982.; cenny jest zwłaszcza wybór artykułów reprezentatywnych dla caloksztaltu badan': Prester John, the Mongols and the Ten Lost Tribes, ed. by Ch.F. B e c k ing ham and B. Hamil t o n, Va r i o r u m 1996, gdzie zamieszczona jest również obszerna bibliografia przedmiotu (s. 291-304). Wśród literatury dostępnej w języku polskim problem ten szerzej omawiaja: J. D e I u m e a u, Historia Raju. Ogród rozkoszy, Warszawa 1996, s. 69-92, J. S t r z e l c z y k, Z dziejów średniowiecznych wyobrażeń o Wschodzie: legendy o mnichu Sergiluszu, prezbiterze Janie i królu Dawidzie, w: idem, Szkice średniowieczne, Poznan 1987, s. 99-110. Interesujące są także tezy historyków rosyjskich, identyfikujących królestwo Księdza Jana z XII-wiecznym kara-kitajskim państwem w Azji Środkowej, zalożonym przez Jelü Taszy; por.: L. Gu mil o v, Śladami cywilizacji wielkiego stepu, Warszawa 1973.

${ }^{4}$ Ottonis episcopi Frisingensis chronica sive historia de duabus civitatibus, editio altera, recognovit A. Hofmeister, "Scriptores rerum Germanicarum in usum scholarum” vol. 15, Hannoverae et Lipsiae 1912, Liber VII, Cap. XXXIII, s. 365-367.

${ }^{5}$ L. Gu milov, op. cit, s. 98-116.

${ }^{6}$ S. Ru n ciman, Dzieje wypraw krzyżowych, Warszawa 1987, t. 3, s. 238.

${ }^{7}$ Obydwa teksty wydał F. Zarncke, Der Presbyter Johannes..., traktat De adventu... s. $831-843$, list opata Odona: s. 843-871.

${ }^{8}$ Edycja listu Aleksandra III - ibidem, s. 935-944.

${ }^{9}$ Ch.F. B ecking ham, The Achievements of Prester John, [w:] Prester John..., s. 11.

${ }^{10}$ Ibidem, s. $11-13$.

${ }^{11}$ Chronica Alberici monachi Trium Fontium a monacho Novi Monasterii Hoiensis interpolata, ed. Paulus Scheffer-Boichorst, Monumenta Germaniae Historica, Scriptores, XXIII, Hannoverae 1874 , s. 848-849.

${ }^{12}$ Ch. F. Beckingha m, op. cit., s. 8.

${ }^{13}$ Twory te nie należą do typowych, powszechnie znanych z bestiariuszy, takich jak gryfy. smoki itp. Próby rozszyfrowania pochodzenia i znaczenia tych nazw relacjonuje V. S le ssa rev, op. cit., s. $42-43$.

${ }^{14} \mathrm{Na}$ temat szczegółowej dyskusji źródeł Listu Księdza Jana, por. M. Le t t s, Prester Jolnn: sources and illustrations, „Notes and Queries”, vol. 188, 1945.

${ }^{15}$ L. Ols c h ki, Der Brief des Presbyters Johannes, „Historische Zeitschrift” 144, 1931, s. 1-14.

${ }^{16}$ Odrębne zagadnienia to recepcja omawianego tekstu w wersji hebrajskiej, ruskiej i serbskiej. Jako problemy niewchodzące $w$ obręb średniowiecznej kultury łacińskiej pozostawiamy je poza ramami niniejszych rozważań.

${ }^{17}$ V. Slessarev, op. cit., s. 4, wspomina np. o czternastu starodrukowych wydaniach francuskich. 
${ }^{18}$ F. Zarncke, Der Presbyter Johannes...; edycja listu na s. 873-934, przedrukowana w: Prester Jolm, the Mongols and the Ten Lost Tribes..., s. 40-102.

"BN IV 8052, k. 222 ${ }^{\mathrm{r}}-223^{\mathrm{V}}$; rękopis ten, w latach siedemdziesiątych XV w. zapewne należat do Jana Dlugosza, a być może byl nawet przez niego skompletowany i przerabiany. Co się tyczy opisu treści, por. J. S os z y ń s ki, Between the Middle Ages and the Renaissance: the Wilanów Manuscript Reconsidered. „Medievalia Philosophica Polonorum”, 34, 2001, s. 199-206 [pisząc ien artykut, nie zdawałem sobie jeszcze sprawy z koneksji Długoszowych tego rękopisu]. Por. także: F. Z a r n cke, Der Presbiter Johamnes..., s. 880.

${ }^{20}$ Kow na cki Hipolit, Kronika wegierska i czeska na poczqtku wieku XII. Kronika czeska na poczalku wieku XI. W Lacinskiem języku pisane; z tlomaczeniem na Polski jezyk. Tudzież ziemopismo Bedy wieku VIII. List popa Jana wieku XIII. Z rękopismów rożnych bibliotek, Warszawa 1823. Tekst Listu Księdza Jana zawarty jest na s. 152-165. Wydanie to w wielu szczegółach odbiega od przekazu w kodeksie wilanowskin.

${ }^{21}$ Faktycznie Kownacki nie wypowiada się we wspomnianej książce na temat datacji rękopisu wilanowskiego w ogóle, lecz jedynie o czasie spisania samego listu. Skądinąd wiadomo (własnoręczne notatki dołączone do rękopisu), że Kownacki zabytek ten datował, również błędnie, na wiek XIV.

${ }^{22}$ F. Z a r n c ke. Der Presbiter Johannes..., s. 879. Zarncke znów oparł się na wiadomościach $z$ drugiej ręki. Rękopis ten nie ma publikowanego opisu katalogowego.

${ }^{23}$ Rękopis ten jest proweniencji krakowskiej i zawiera pisma dot. tematyki orientalnej, teologiczne oraz kazania; spisany zosta\} w 1441 r.; por.: Catalogus codicum manuscriptorum medii aevii Latinorum, qui in Bibliotheca Jagellonica asservantur, Vol. 4: Nos. 564-667, composuerunt M. Kow a 1 c zyk, A. Koz lowska, M. Markowski, Z. Wlodek, J. Zathey, M. Zwie rcan, Wroclaw 1988, s. 307-311.

${ }^{24}$ W. W is 1 o c k i, Katalog rękopisów Biblioteki Uniwersytetu Jagielloriskiego, cz. 1-2, Kraków 1877-1881, s. 388-389 (opis). Jest to klocek pierwotnie stanowiący dwa odrębne tomy. Poszczególne teksty spisane zostaly w latach $1434-37$ przez kilku kopistów, m.in. Mikolaja ze Slupnik i kleryka Piotra. W 1460 r. nabył go magister Andrzej ze Stargardu, dziekan wydziału sztuk wyzwolonych na Uniwersytecie Krakowskim; odtąd zapewne nieprzerwanie przebywał w zbiorach uniwersyteckich. Rękopis nie ma jednolitego charakteru; zawiera komentarze i pisma o treści teologicznej, egzempla, krotkie rymy itp. oraz List Księdza Jana.

${ }^{25}$ F. Z a r n c ke, Der Presbiter Johannes..., s. 887.

26 Ibidem, s. 899-900.

27 Por. F. Pulaski, Opis 815 rękopisów Biblioteki Ordynacji Krasiniskich, nr 83, s. 78-83 oraz W. Kamieniecki, Straty Biblioteki Ordynacji Krasinskich w zakresie zbiorów rękopiśmiennych, w: Straty bibliotek $i$ archiwów warszawskich w zakresie rękopismiennych żódel historycznych, t. 3: Biblioteki, pod red. P. Bańkowskiego, Warszawa 1955, s. 150-151. 